УАК 616.314.17-008.1:616.379-008.64

(С). М. Якимець, М. З. Безкоровайна, М. Я. Пинда

АВНЗ «Тернопільський державний медичний університет імені І. Я. Горбачевського»

\title{
Порівняльний аналіз стану тканин пародонта у хворих на цукровий діабет 1 та 2 типів
}

\begin{abstract}
Резюме. У даній статті розглянуто особливості клінічного перебігу захворювань тканин пародонта при інсулінозалежному та інсулінонезалежному типах цукрового діабету. Отримано кількісну оцінку тканин пародонта, за даними ортопантомограм, що підтвердило тяжкість перебігу патології пародонта при цукровому діабеті 2 типу.
\end{abstract}

Ключові слова: цукровий діабет, пародонтит, ортопантомограма.

\section{М. Н. Якимец, М. З. Безкоровайная, М. Я. Пинда}

ГВУЗ «Тернопольский государственный медицинский университет имени И. Я. Горбачевского»

\section{Сравнительный анализ состояния тканей пародонта у больных сахарным диабетом 1 и 2 типов}

\begin{abstract}
Резюме. В данной статье рассмотрены особенности клинического течения заболеваний тканей пародонта при инсулинзависимом и инсулиннезависимом типах сахарного диабета. Получено количественную оценку тканей пародонта, по данным ортопантомограммы, что подтвердило тяжесть протекания патологии пародонта при сахарном диабете 2 типа.
\end{abstract}

Ключевые слова: сахарный диабет, пародонтит, ортопантомограмма.

M. M. Yakymets, M. Z. Bezkorovaina, M. Ya. Pynda

SHEI «Ternopil State Medical University by I. Ya. Horbachevsky»

\section{Comparative analysis of the periodontal tissues in patients with diabetes mellitus type 1 and 2}

Summary. This article reviews the clinical course of disease periodontal tissues in insulin-dependent and non-insulin dependent type of diabetes. The quantitative evaluation of periodontal tissues, according ortopantomohram that confirmed the severity of periodontal pathology occurrence in diabetes type II.

Key words: diabetes mellitus, parodontitis, panoramic X-ray.

Вступ. Цукровий діабет (ЦА) - клінічно і генетично гетерогенне захворювання, що характеризується абсолютною або віднос- ною інсуліновою недостатністю і периферичною резистентністю тканин до інсуліну $[1,2]$. Цукровий діабет 2 типу зустрічається майже

ISSN 231 1-9624. Клінічна стоматологія. 2014 . № 2 
в 20 разів частіше, ніж інсулінозалежний діабет, а його частка серед інших форм досягає $85-90 \%$ [3, 4]. Крім того, на даний час фрактична поширеність ЦА 2 типу в $2-3$ рази перевищує його реєстроване поширення, тобто кількість тих, хто звертається, значно менша від кількості хворих [5]. Частота уражень тканин і органів порожнини рота при цукровому діабеті становить від 52 до 90 \% (Т. І. Ібрагімов, I. Ю. Лебеденко, С. А. Арутюнов, 2001), захворювань слинних залоз - від 3 до 34 \% (I. I. Черкасова, 1997). Клінічні дані переконливо вказують на залежність між зниженням функцій слинних залоз і наявністю різних захворювань ендокринного генезу (М. Г. Рибакова, 1984), натомість захворювання слинних залоз є ще однією патогенетичною ланкою розвитку та підтримки патологічних змін у пародонті.

Разом із тим, ряд авторів вказує на розбіжність вираження клінічних і ренттенологічних даних. Так, у хворих молодого віку, які страждають від цукрового діабету, ускладненого явищами гінгівіту, а також у випадку клінічно інтактного пародонта рентгенологічно можуть відмічатися зміни, які характеризуються деструкцією кортикальної пластинки міжзубних перегородок чи резорбцією альвеолярного відростка [6, 7].

Метою дослідження було порівняти вплив інсулінозалежного та інсулінонезалежного типів цукрового діабету на стан тканини пародонта і оцінити, за даними клінічного обстеження, фізичні властивості слини.

Матеріали і методи. Аля вирішення поставленої мети ми провели клінічне обстеження 103 пацієнтів із визначенням стоматологічного статусу, з яких 29 склали контрольну групу, в яку ввійшли практично здорові особи без стоматологічної патології. Аосліджувану групу склали 74 хворих із пародонтитом на тлі цукрового діабету, яких обстежували на базі ендокринологічного відділення клінічної лікарні в Тернопільській області. Серед обстежених 39 пацієнтів (віком 25-40), які хворіють на цукровий діабет 1 типу, 35 пацієнтів (віком від 40 - 55) хворіють на цукровий діабет 2 типу. Серед обстежених було:

17 пацієнтів - з 1 типом цукрового діабету, які хворіють до 10 років;

22 пацієнти - з 1 типом цукрового діабету, які хворіють більше 10 років;

18 пацієнтів - з 2 типом цукрового діабету, які хворіють до 5 років;
17 пацієнтів - чоловіки з 2 типом цукрового діабету, які хворіють більше 5 років.

Аля кількісної оцінки стану пародонта ми провели аналіз ортопантомограм 24 хворих на цукровий діабет [8].

Результати досліджень та їх обговорення. Порівняльний аналіз стану тканин пародонта у хворих на цукровий діабет 1 та 2 типів показав деякі особливості перебігу патологічних змін у тканинах пародонта залежно від тривалості перебігу основного захворювання, ступеня компенсації і типу.

При об'єктивному обстеженні зміну рельєфу ясенного краю частіше спостерігали у пацієнтів з тривалим перебігом основного захворювання, зокрема при 2 типі цукрового діабету декомпенсованої форми. Аналогічну картину виявляли і щодо кровоточивості ясен та наявності зубного каменя (табл. 1).

При зондуванні пришийкової ділянки ясен було виявлено кровоточивість I ступеня у хворих на цукровий діабет 1 типу в 63,5 \% випадків, у пацієнтів із цукровим діабетом 2 типу - у 34,3 \% випадків, однак кровоточивість II ступеня значно частіше виявляли у хворих на цукровий діабет 2 типу і складала 25,8 \%, тоді як у пацієнтів із цукровим діабетом 1 типу цей показник не перевищував 6,8 \%, що також може бути опосередкованою ознакою більшої агресивності цукрового діабету 2 типу. Крім того, частота виявлення кровоточивості безпосередньо залежала від тривалості основного захворювання, як це видно з таблиці 1.

Над- і під'ясенний камінь однозначно частіше виявляли у хворих із цукровим діабетом 2 типу, що перебувало у прямій залежності від тривалості перебігу цукрового діабету. Гноєтечу з пародонтальних кишень було виявлено у 8,6 \% хворих із кількості обстежених.

Варто зауважити, що зміну рельєфу ясенного краю частіше спостерігали у пацієнтів, які хворіють на цукровий діабет довготривало, а саме: у групі пацієнтів з цукровим діабетом 1 типу, де тривалість захворювання була більшою за 10 років, відсоток складав 72,2%, а при цукровому діабеті 2 типу з тривалістю більше 5 років - 64,7 \%. Такі прояви вказують на залежність частоти кровоточивості ясен та наявності зубного каменя від тривалості перебігу основного захворювання.

Таким чином, підсумовуючи отримані дані, можна зробити висновок, що поширення i 
Таблиця 1. Показники захворюваності тканин пародонта у хворих на цукровий діабет 1 та 2 типів ( у\%)

\begin{tabular}{|l|c|c|c|c|}
\hline \multirow{2}{*}{ Показник } & \multicolumn{2}{|c|}{$\begin{array}{c}\text { Цукровий діабет 1 типу } \\
\text { (пацієнти віком від 25-40 років) }\end{array}$} & \multicolumn{2}{|c|}{ Цукровий діабет 2 типу } \\
\cline { 2 - 5 } & $\begin{array}{c}\text { хворіють до } \\
10 \text { років }\end{array}$ & $\begin{array}{c}\text { хворіють після } \\
10 \text { років }\end{array}$ & $\begin{array}{c}\text { хворіють до } \\
5 \text { років }\end{array}$ & $\begin{array}{c}\text { хворіють після } \\
5 \text { років }\end{array}$ \\
\hline Консистенція ясен: пружні & 64,7 & 22,7 & 33,3 & 23,6 \\
\hline Рихлі & 35,3 & 72,7 & 61,1 & 64,7 \\
\hline Стовщені & 5,9 & 4,5 & 5,6 & 11,76 \\
\hline Кровоточивість ясен: І ст. & 58,8 & 68,2 & 33,3 & 35,3 \\
\hline ІІ ст. & 0 & 13,6 & 22,2 & 29,4 \\
\hline ІІІ ст. & 0 & 0 & 0 & 0 \\
\hline Зубний наліт на 1/3 коронки зуба & 70,6 & 77,3 & 66,7 & 82,4 \\
\hline Зубний наліт на 2/3 коронки зуба & 5,9 & 9,1 & 22,2 & 0 \\
\hline Над’ясенний зубний камінь & 35,3 & 45,5 & 55,6 & 70,6 \\
\hline Під’ясенний зубний камінь & 29,4 & 54,5 & 44,4 & 58,8 \\
\hline Ступінь рухомості зубів: І ст. & 5,9 & 18,2 & 5,6 & 17,7 \\
\hline ІІ ст. & 5,9 & 0 & 11,1 & 29,4 \\
\hline ІІІ ст. & 0 & 0 & 5,6 & 5,9 \\
\hline
\end{tabular}

глибина змін у тканинах пародонта і слинних залозах та їх клінічні прояви у хворих на цукровий діабет перебувають в прямій залежності від ступеня тяжкості та форми і тривалості перебігу цукрового діабету.

Пародонтальний синдром при цукровому діабеті 1 типу в групі пацієнтів віком від 2540 років, які хворіють на цукровий діабет менше 10 років, практично не спостерігається. Ру- хомість зубів I та II ступенів відмічали у 5,9% обстежених; консистенцію ясен у 64,7 \% пружні, 35,3 \% - рихлі, над'ясенний зубний камінь виявлено у 35,3 \%, під' ясенний зубний камінь у 29,4 \% пацієнтів, що і підтверджувалось рентгенологічно.

Тоді, коли у групі пацієнтів із ЦА 1 і 2 типів 3 тривалим перебігом захворювання ці ж симптоми мають вищі показники.

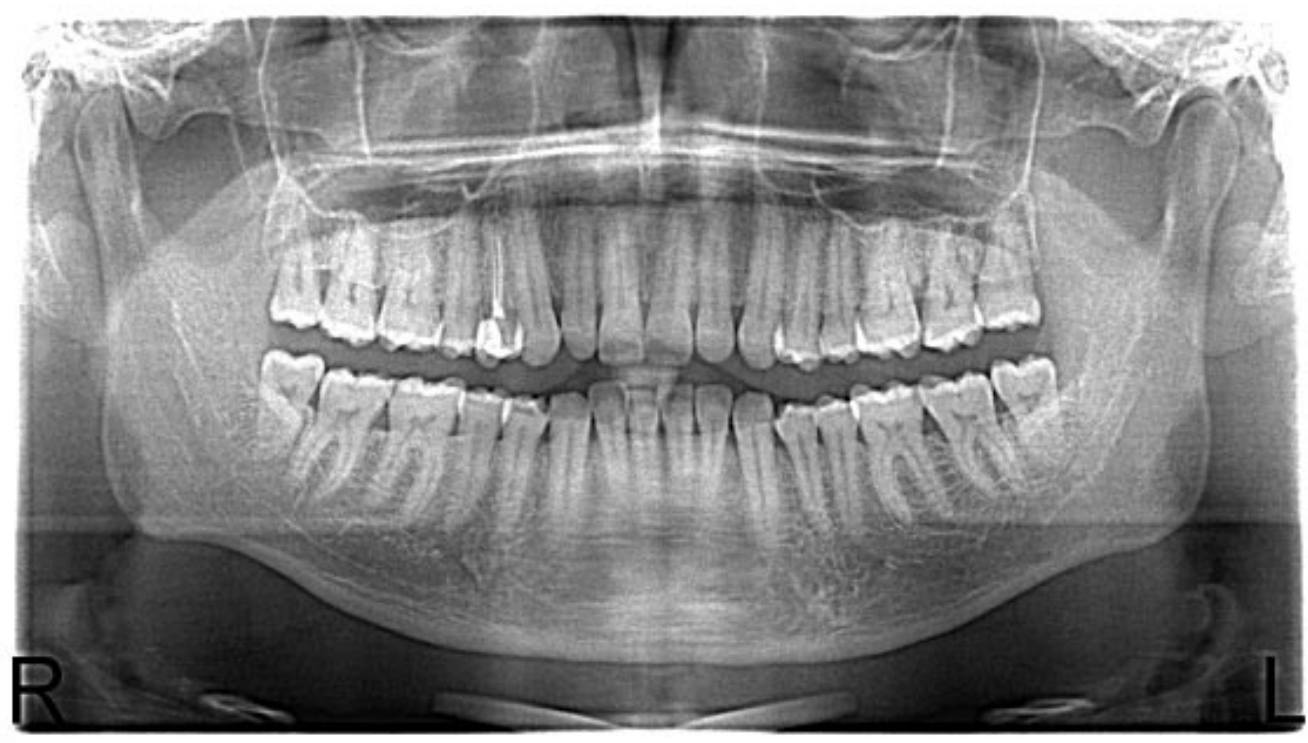

Рис. 1. Вертикальний тип резорбції кісткової тканини з нерівномірною деструкцією кортикальної пластинки в ділянці верхівок міжкоміркових перегородок. Зміна структури кісткових балок із тенденцією до великопетлистого рисунка. Розширення періодонтальної щілини близько міжкоміркових перегородок. Пацієнт М., 29 років, цукровий діабет 1 типу з тривалістю захворювання до 10 років. 


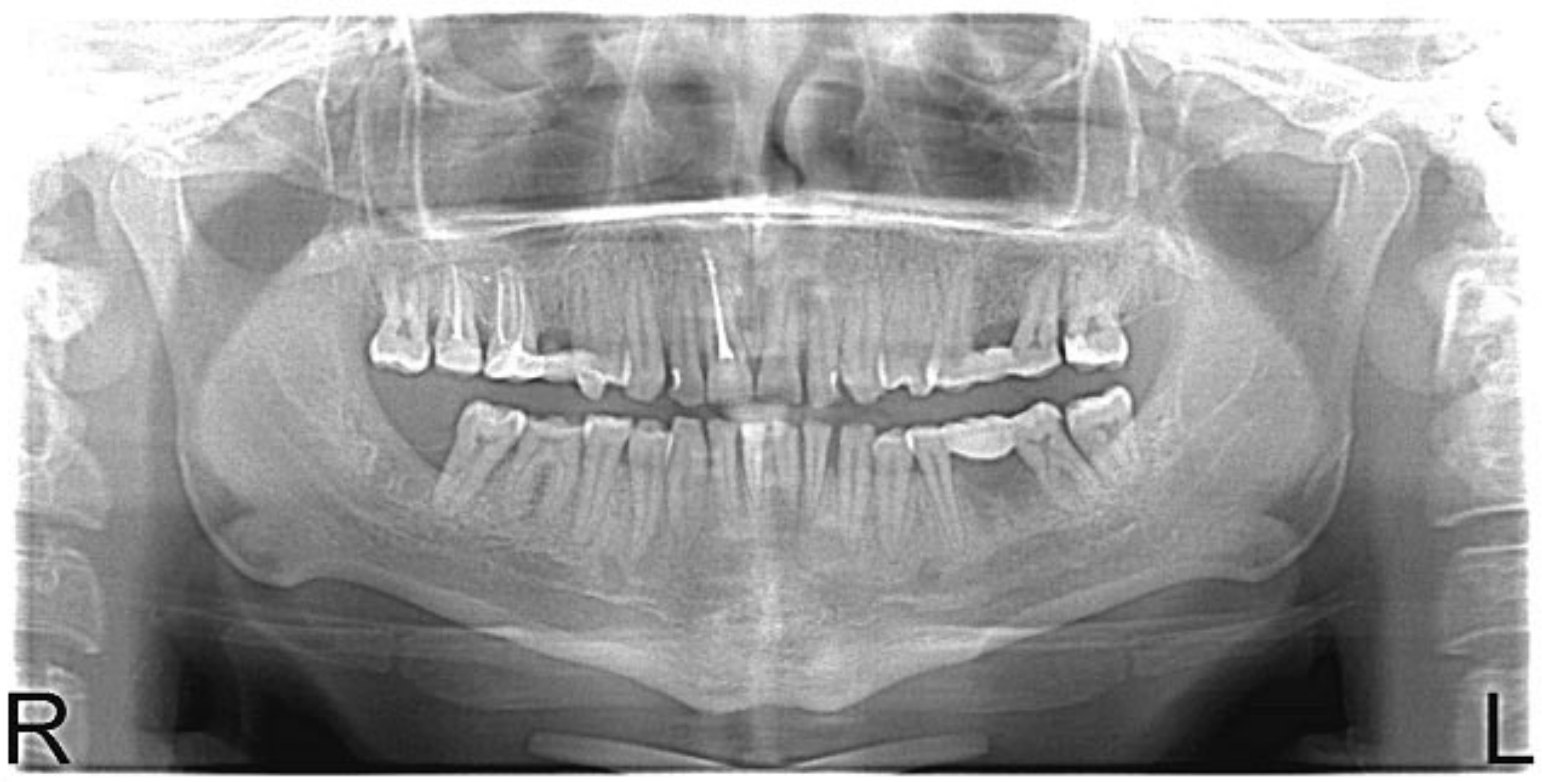

Рис. 2. Вертикальний тип резорбції кісткової тканини з нерівномірною деструкцією кортикальної пластинки в ділянці верхівок міжкоміркових перегородок. Зміна петлистості кісткових балок із формуванням великопетлистого рисунка. Пацієнт Р., 25 років, цукровий діабет 1 типу 3 тривалістю захворювання більше 10 років.

Рухомість зубів І ступеня - у середньому $17-18$ \% при 2 та 1 типах ЦА, однак II та III ступені рухомості у пацієнтів з 1 типом не відмічали, а у пацієнтів з 2 типом - у 29,4 \%, III ступеня 5-6 \%. Близькою до цього була динаміка змін консистенції ясен. Всі цідані вказують на прогресування хвороб пародонта, а тому і пародонтиту, як запально-дистрофрічного процесу на фоні цукрового діабету, що має генералізований хронічний перебіг у пацієнтів з 2 типом ЦА.

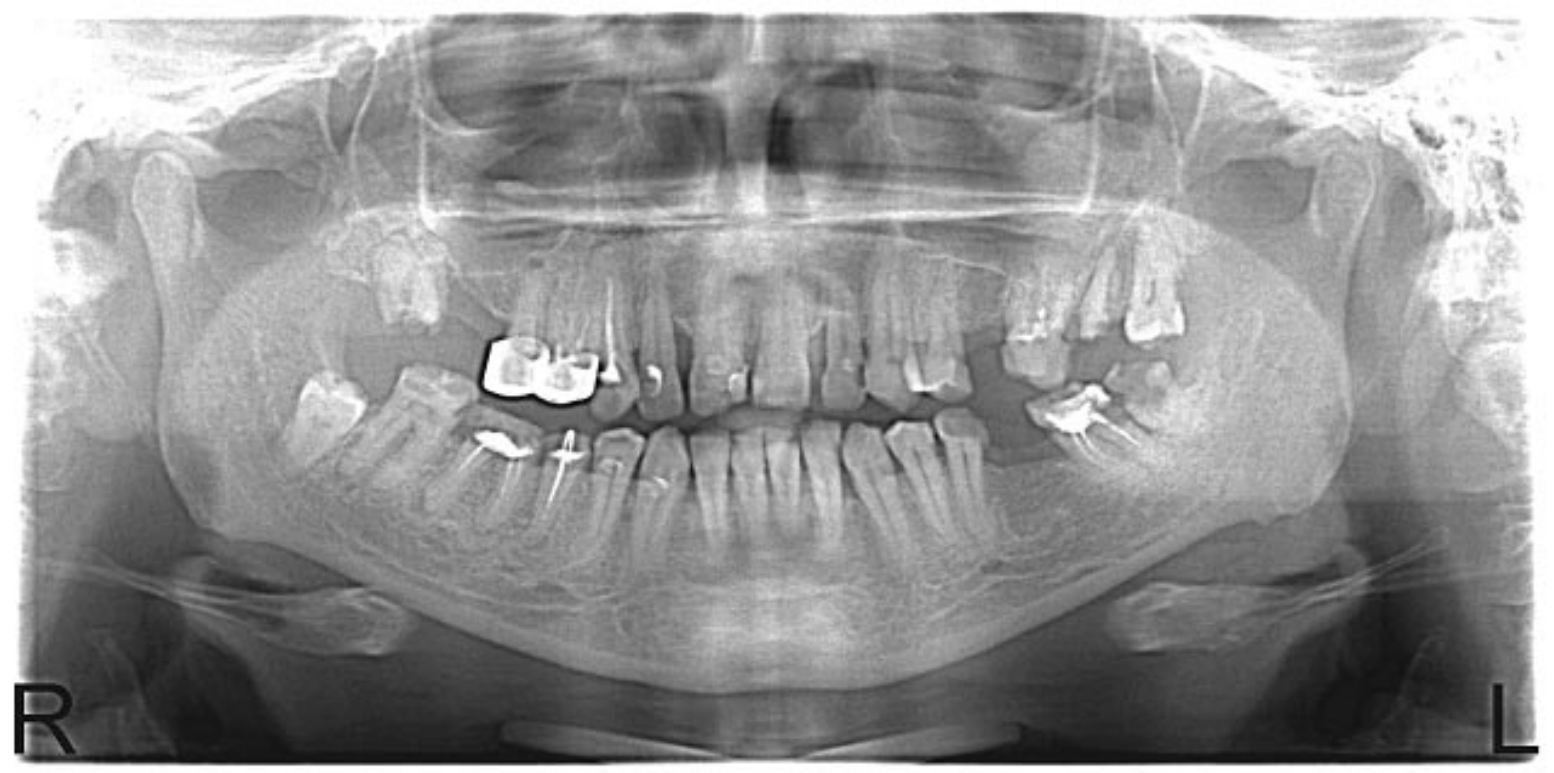

Рис. 3. Нерівномірна деструкція вершин міжкоміркових перегородок із розширенням періодонтальної щілини. Наявні ознаки остеопорозу, що характеризувались зміною структури кісткових балок із тенденцією формування великопетлистого рисунка. Пацієнт I., 45 років, цукровий діабет 2 типу з тривалістю захворювання 4 роки. 
Як свідчать дані таблиці 2, гіперемію слизової оболонки спостерігали в досить значної частини пацієнтів (від 11,76 до 58,72% ), що вказує саме на хронічний перебіг у них запального процесу. Кількісно ця ознака переважала у пацієнтів з 2 типом цукрового діабету. Причому у хворих з 2 типом захворювання можна було відмітити дещо більшу інтенсивність впливу загального патологічного процесу на стан пародонта, ніж у хворих з 1 типом, що може бути результатом вікових змін та тривалості захворювання на цукровий діабет у пацієнтів даної групи.

При зборі анамнезу значна кількість пацієнтів скаржилась на відчуття сухості сли- зових оболонок губ, язика, порожнини рота (табл. 2).

Всі ці симптоми за часом співпадали, як правило, з початком декомпенсації або з вираженою декомпенсованою стадією розвитку цукрового діабету. Хворі з компенсованою формою відмічали лише періодичну сухість слизової оболонки порожнини рота при хвилюванні (36 \%), при довгій розмові (24 \%) та при споживанні їжі (12\%). У пацієнтів із декомпенсованою формою цукрового діабету слина, порівняно із випадками компенсованого перебігу, Аосить часто була мутною і густою (19 \%), що є ознакою патологічного функціонування слинних залоз.

Таблиця 2. Суб'єктивні дані про стан слизової оболонки порожнини рота та червоної кайми губ у хворих на цукровий діабет 1 та 2 типів ( у \%)

\begin{tabular}{|l|c|c|c|c|}
\hline \multirow{2}{*}{ Показник } & \multicolumn{2}{|c|}{$\begin{array}{c}\text { Цукровий діабет 1 типу } \\
\text { (вік паціснтів 25-40 років) }\end{array}$} & \multicolumn{2}{|c|}{$\begin{array}{c}\text { Цукровий діабет 2 типу } \\
\text { (вік пацієнтів від 40-55 років) }\end{array}$} \\
\cline { 2 - 5 } & $\begin{array}{c}\text { хворіють } \\
\text { до 10 років }\end{array}$ & $\begin{array}{c}\text { хворіють } \\
\text { після 10 років }\end{array}$ & $\begin{array}{c}\text { хворіють } \\
\text { до 5 років }\end{array}$ & $\begin{array}{c}\text { хворіють } \\
\text { після 5 років }\end{array}$ \\
\hline Сухість в порожнині рота: постійна & 0 & 13,64 & 22,22 & 17,65 \\
\hline Тимчасова (при хвилюванні) & 47,06 & 45,45 & 27,78 & 58,82 \\
\hline При довгій розмові & 17,65 & 22,73 & 22,22 & 47,06 \\
\hline Під час споживання іжі & 35,29 & 18,18 & 11,11 & 17,65 \\
\hline Влітку & 11,76 & 13,64 & 0 & 17,65 \\
\hline Сухість губ & 17,65 & 27,27 & 27,78 & 29,41 \\
\hline Лусочки на губах & 5,88 & 9,09 & 0 & 0 \\
\hline СОПР: зволожена & 82,35 & 77,27 & 66,67 & 88,24 \\
\hline Суха & 17,65 & 22,73 & 27,78 & 11,76 \\
\hline $\begin{array}{l}\text { Гіпермійована слизова оболонка } \\
\text { порожнини рота }\end{array}$ & 11,76 & 22,73 & 44,44 & 58,82 \\
\hline
\end{tabular}

При об'єктивному обстеженні слинних залоз у більшості випадків (89 \%) пальпаторно їх тканини були еластичними, однак в 11 \% випадків (особливо в пацієнтів із тривалим перебігом основного захворювання) їх консистенція ставала більш щільною. При оцінці стоматологічного статусу хворих на цукровий діабет звертали увагу на сухість слизової оболонки порожнини рота, періодичність її виникнення та фізичні властивості слини (табл. 3).

При масажі залоз із їх вивідних проток виділялася прозора слина (у середньому в 91,7 \% обстежених), що говорить про задовільне функціонування вказаних органів. Однак у середньому в 8,3 \% пацієнтів (переважно з тривалим перебігом захворювання) слина була густою і мутною, що може бути оцінено як наслідок розвитку в епітелії залоз дистрофічних процесів. Колір шкірних покривів у ділянці слинних залоз був без видимих патологічних змін. Враховуючи те, що більшість пацієнтів перебувала в стадії субкомпенсації основного захворювання, то виражені клінічні прояви декомпенсації стосовно функцій слинних залоз спостерігалися відносно рідко (8,3%).

Щодо рентгенологічних змін, то при розвитку цукрового діабету в пацієнтів обох груп на ортопантомограмах спостерігався вертикальний тип резорбції кісткової тканини, який підтверджувався нерівномірною деструкцією кортикальної пластинки в ділянці верхівок міжкоміркових перегородок та наявністю 
Таблиця 3. Фізичні властивості змішаної слини у пацієнтів з 1 та 2 типами цукрового діабету (у \%)

\begin{tabular}{|c|c|c|c|c|}
\hline \multirow{2}{*}{$\begin{array}{c}\text { Характеристика } \\
\text { слини }\end{array}$} & \multicolumn{2}{|c|}{$\begin{array}{c}\text { Цукровий діабет } 1 \text { типу } \\
\text { (пацієнти віком від 25-40 років) }\end{array}$} & \multicolumn{2}{|c|}{$\begin{array}{c}\text { Цукровий діабет } 2 \text { типу } \\
\text { (пацієнти вікомвід 40-55 років) }\end{array}$} \\
\hline & $\begin{array}{c}\text { хворіють } \\
\text { до } 10 \text { років }\end{array}$ & $\begin{array}{c}\text { хворіють } \\
\text { після } 10 \text { років }\end{array}$ & $\begin{array}{l}\text { хворіють } \\
\text { до } 5 \text { років }\end{array}$ & $\begin{array}{c}\text { хворіють } \\
\text { після } 5 \text { років }\end{array}$ \\
\hline Рідка & 82,35 & 77,27 & 72,22 & 76,47 \\
\hline Густа & 11,76 & 22,73 & 27,78 & 17,65 \\
\hline Мутна & 11,76 & 4,55 & 16,67 & 0 \\
\hline Прозора & 82,35 & 95,45 & 88,89 & 100 \\
\hline Піниста & 5,88 & 0 & 0 & 0 \\
\hline
\end{tabular}

вогнищ остеопорозу (у вигляді зон просвітлення, формування великопетлистого рисунка кісткових балок). Кількісні показники оцінки ортопантомограм пацієнтів з меншою тривалістю цукрового діабету як при 1, так і при 2 типах, підтвердили зменшення співвідношення між висотою коронки зуба і шийки в середньому на 55 - 60 \% і співвідношення між довжиною кореневого каналу і відстанню від анатомічної до рентгенологічної верхівки в середньому на $43-47$ \%, натомість наростання співвідношення між висотою шийки і довжиною кореня на 15 - 17 \%, при суттєво незмінному співвідношенні між висотою шийки й довжиною кореня, хоча можна було спостерігати тенденцію до його зниження у фрронтальній групі зубів і деякого підвищення у великих корінних зубів. Зменшення співвідношення між висотою коронки зуба і шийки й одночасне збільшення співвіАношення між висотою шийки й довжиною кореня може бути пояснено розвитком явищ остеопорозу з розвитком резорбції міжальвеолярних перегородок, як результат порушення трофріки та обмінних процесів у тканинах пародонта. Зниження показника співвідношення між висотою коронки і довжиною кореня у фронтальній групі зубів може свідчити про формування вторинних деформацій зубоальвеолярного комплексу, за наявності патологічної рухомості зубів, створенні передчасних контактів, травматичних ключів оклюзії.

При тривалішому впливі цукрового діабету (1 тип - більше 10 років, 2 - тип більше 5 років) відмічені попередньо явища з їх кількісними характеристиками частково стабілізувалися, хоча по окремих зубах можна було спостерігати їх прогресування, однак його темпи значно сповільнювалися. Це може бути пояснено тим, що при подальшому прогресуванні процесу настає втрата зубів, що й відмічалося на більшості ортопантомограм у даної частини пацієнтів. Візуальний аналіз ортопантомограм хворих із тривалим перебігом цукрового діабету дозволив підтвердити поглиблення процесів вертикальної резорбції кісткової тканини з нерівномірною деструкцією кортикальної пластинки в ділянці верхівок міжкоміркових перегородок та виникненням вогнищ остеопорозу з рентгенологічним просвітленням кісткової тканини. Резорбція міжальвеолярних перегородок сягала 1/2 довжини кореня, що клінічно відповідає II ступеню тяжкості перебігу пародонтиту.

Таким чином, результати клінічного обстеження хворих на цукровий діабет, які перебували на стаціонарному лікуванні в ендокринологічному відділенні КЗ ТОР «Тернопільська університетська лікарня», показали, що у всіх обстежених є патологія пародонта і порушення функції слинних залоз, що проявлялось низьким рівнем гігієни, гінгівітом, кровоточивістю ясен після зондування, наявністю над- і під'ясенного зубного каменя, генералізованим запаленням пародонта, гіперемією слизової оболонки порожнини рота, виділенням густої і мутної слини. На фоні декомпенсованої форми основного захворювання створюються сприятливі умови для розвитку патогенної мікрофлори, що, у свою чергу, веде до підтримки патологічних процесів у тканинах пародонта і слинних залозах.

Висновки. При обстеженні у всіх хворих на цукровий діабет виявлено порушення стоматологічного статусу, що вказує на прямий зв'язок основного захворювання та стоматологічних ускладнень. Патологічні зміни пародонта характеризувались гінгівітом, крово- 
точивістю ясен, наявністю над- і під'ясенного зубного каменя, гноєтечею з пародонтальних кишень, рухомістю зубів I - III ступенів.

2. Візуальна та кількісна оцінка ортопантомограм хворих на цукровий діабет підтвердила наявність нерівномірної резорбції між альвеолярними перегородками різного ступеня тяжкості, а також підтвердили поглиблення процесів резорбції кісткової тканини пародонта у пацієнтів з тривалим впливом цукрового діабету, особливо у хворих з 2 типом.

\section{Список літератури}

1. Аедов И. И. Введение в диабетологию : руководство для врачей / И. И. Аедов, В. В. Фадеев. - М. : ИзА-во «Берег», 1998. - 200 с.

2. Аедов И. И. Микроангиопатии / И. И. Аедов // Сахарный диабет. - 1998. - № 1. - С. $7-21$.

3. Janka H. U. Epidemiology of diabetes mellitus: Prevalence, incidence, pathogenesis, and prognosis / H. U. Janka, D. Michaelis // Z. Arztl. Fortbild. Qualitatssich. - 2002. - Vol. 96, № 3. - P. 159-165.

4. Zimmet P. Kelly West Lecture 1991 - Challenges in diabetes epidemiology - From west to the rest / P. Zimmet // Diabetes Care. - 1992. - Vol. 15. P. $232-252$.
3. Порушення функції слинних залоз характеризується гіперемією слизової оболонки порожнини рота, сухістю порожнини рота при хвилюванні, довгій розмові та споживанні їжі, виділенням густої і мутної слини з вивідних проток слинних залоз.

4. Хворі на цукровий діабет потребують ретельної гігієни порожнини рота та адекватної комплексної профілактики й одночасного лікування основного захворювання і стоматологічних ускладнень, зокрема захворювань пародонта.

5. Garancini M. P. Prevalence of NIDDM and impaired glucose tolerance in Italy: An OGTT-based population study / M. P. Garancini // Diabetologia. - 1995. Vol. 38. - P. $306-313$.

6. Рабухина Н. А. Рентгенодиагностика в стоматологи / Н. А. Рабухина, А. П. Аржанцев. - М. : МИА. 1999. -452 c.

7. Рабухина Н. А. Рентгенодиагностика в стоматологии / Н. А. Рабухина, А. П. Аржанцев. - Москва : Мед. информ. Агентство «Миа», 2003. - 456 с.

8. Герасимюк I. Є. Оцінка стану пародонта у хворих на цукровий діабет за результатами кількісного аналізу ортопантомограм / I. Є. Герасимюк, М. М. Якимець, А. Я. Федонюк // Вісник морфології. - 2010. T. 16, № 4. - C. $857-861$. 